\title{
Tradução e adaptação transcultural do protocolo Kaufman Speech Praxis Test for Children (KSPT)
}

A tradução, a adaptação e a normatização de instrumentos de avaliação podem ser mais viáveis do que a elaboração de um instrumento novo, uma vez que já apresentam informações da sua validação em outra língua. Assim, os objetivos deste estudo foram: realizar a tradução e a adaptação transcultural do instrumento Kaufman Speech Praxis Test for Children - KSPT; e verificar a aplicabilidade do instrumento em crianças na faixa etária de dois a seis anos com desenvolvimento normativo, com hipótese diagnóstica de AFI e com diagnóstico de Transtorno do Espectro Autista. O estudo foi organizado em duas fases sucessivas e complementares. Na fase 1 foram realizadas a tradução e a adaptação transcultural do teste "Kaufman Speech Praxis Test-KSPT" para o português do Brasil. A fase 2 consistiu na aplicação do instrumento em três grupos distintos, compostos por crianças com idades entre dois a seis anos: G1 composto por crianças com desenvolvimento típico; G2 por crianças com diagnóstico de AFI; e G3 por crianças com diagnóstico de Transtorno do Espectro Autista. A avaliação foi realizada utilizando-se o Teste de Triagem do Desenvolvimento de Denver-II (TTDD-II), o KSPT e os critérios diagnósticos do DSM 5 para o G3. Após procedimentos de tradução e adaptação transcultural, não houve mudanças em relação às ordens a serem realizadas na Parte 1 (Nível de movimento oral); na Parte 2 (Nível silábico e fonêmico simples), 12 palavras-teste foram excluídas e 16 incluídas, além disso, ampliou-se o teste com a prova de trissílabas simples; e na Parte 3 (Nível silábico e fonêmico complexo), 13 palavrasteste foram excluídas por não apresentarem correspondência em relação às características de produção fonoarticulatória (fonético/fonológico) no Português Brasileiro. Na parte 4 (Extensão e complexidade espontânea medida subjetiva) não houve alterações da versão em inglês do KSPT. Para a tradução do Manual de aplicação e do guia de teste clínico, foram seguidas as etapas de tradução, retrotradução, e comparação entre versões com um Comitê de Especialistas, com a tradução de 4530 
palavras do manual, e 1315 do guia de teste clínico. O teste KSPT demonstrou-se viável nos três grupos aplicados. A tradução do KSPT foi finalizada com mudanças em palavras-teste do protocolo de aplicação a fim de respeitar as características transculturais da língua portuguesa falada no Brasil. Foram respeitadas as equivalências semântica, idiomática, experimental e conceitual tanto no manual de aplicação quanto no guia de teste clínico e nos enunciados das provas. Espera-se que o instrumento possa contribuir efetivamente para o diagnóstico e acompanhamento de procedimentos de intervenção.

Descritores: apraxia, dispraxia, testes de articulação da fala, transtornos da articulação, tradução transcultural, tradução. 


\section{Translation and cross-cultural adaptation of the Kaufman Speech Praxis Test for Children (KSPT) protocol}

The translation, adaptation and standardization of assessment instruments may be more viable than the development of a new instrument, as they already have validation information in their language. Thus, the objectives of this study were: to carry out the translation and cross-cultural adaptation of the instrument Kaufman Speech Praxis Test for Children - KSPT; and to verify the applicability of the instrument in children aged from two to six years with normative development, with a CAS diagnostic hypothesis, and with a diagnosis of Autistic Spectrum Disorder. The study was organized in two successive and complementary phases. In phase 1, the translation and the cross-cultural adaptation of the Kaufman Speech Praxis Test-KSPT to Brazilian-Portuguese language were performed. Phase 2 consisted of the instrument application in three distinct groups, composed of children aged between two and six years: G1 composed of children with typical development; G2 of children diagnosed with CAS; and G3 of children diagnosed with Autistic Spectrum Disorder. The assessment was performed using the Denver Developmental Screening Test-II (TTDD-II), the KSPT and the DSM-5 diagnostic criteria for G3. After translation and cross-cultural adaptation procedures, there were no changes regarding the orders to be performed in Part 1 (Oral movement level); in Part 2 (Simple syllabic and phonemic level), 12 test words were excluded and 16 were included, in addition, the test was expanded with a test of simple trisyllables; and in Part 3 (complex syllabic and phonemic level), 13 test words were excluded because they failed to match the characteristics of articulatory production (phonetic/phonological) in Brazilian Portuguese. In part 4 (Spontaneous length and complexity - subjective measure), there were no changes in the English version of the KSPT. For the translation of the Manual and the Clinician's guide, the steps of translation, back-translation, and comparison between versions with a committee of experts were followed, with the translation of 4530 words in the Manual, and 1315 in the Clinician's guide. The KSPT test proved to be viable in the three applied groups. The KSPT translation was completed with changes in 
test words of the application protocol in order to respect the cross-cultural characteristics of the Portuguese language spoken in Brazil. Semantic, idiomatic, experimental and conceptual equivalences were respected in the Manual, in the Clinician's guide and in the test statements. This instrument is expected to effectively contribute to the diagnosis and monitoring of intervention procedures.

Descriptors: apraxia, dyspraxia, speech articulation tests, articulation disorders, cross-cultural translation, translation. 